\title{
Til skolebal i nisseland
}

Om eventyret som tilflugtssted for born og barnlige sjale - og om et eventyrligt skolefors $\emptyset \mathrm{g}$ a a Frederiksberg $i$ begyndelsen afforrige ärbundrede.

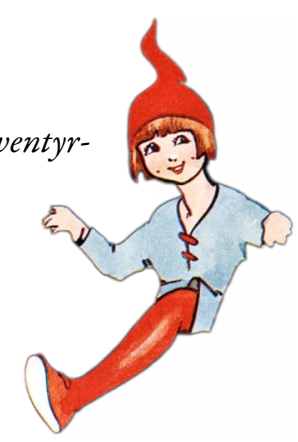

lle voksne har prøvet at trøste et
barn. Det er forholdsvis nemt,
hvis det er noget med hul på knæet eller fald fra cyklen; det er straks sværere, hvis det drejer sig om angst eller utryghed. I dag vil de fleste nok vælge at gå ind på barnets oplevelse og tale med det om rædslerne, hvor man tidligere havde langt mere rationelle, håndfaste og indimellem også adfærdsregulerende metoder.

Børnepsykologen Bruno Bettelheim (1903-1990), der havde været i tysk koncentrationslejr og derfor vidste en del om overlevelsesmekanismer og bøddelofferdynamik, udviklede en teori om, at de ofte grumme folkeeventyr kunne tale til barnets ubevidste med en bearbejdende og terapeutisk virkning til følge. ${ }^{1}$ De fleste folkeeventyr handler jo om børn, der sendes alene ud i store skove, forgiftes eller mishandles af (sted)mødre, eller udsættes for hekse og trolde, der vil æde dem. Bettelheim mente, at barnet kunne genkende sig selv og sin angst i disse grumme fortællinger, og at det derved - bistået af en empatisk og klog voksen - kunne lære at håndtere angsten. Børn, der vågner og græder om natten, eller børn, der ikke tør sove, skal altså ikke have bortforklaringer, som at der umuligt kan ligge et uhyre under sengen, eller at mor og far ikke dør mens barnet sover - de skal have empati. Og eventyrlæsning.

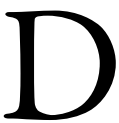
et kan være grumt at være barn, og det har de fleste glemt, når de bliver voksne. Det må have været særlig grumt at være lille Niels (født 1911): Hans mor var ganske vist succesforfatter og del af den københavnske avantgarde, tilhænger af kvindefrigørelse og selvstændighedsfremmende børneopdragelse, men hun var en elendig mor. $\mathrm{Og}$ hun havde valgt at fà sit fjerde barn, Niels, uden at være gift med barnefaderen, der også var en kendt forfatter. Det stormomsuste forhold havde været samtaleemne ved borgerskabets middagsborde i København i flere år, men kort før Niels' fødsel var det endegyldigt slut, og frugten af det voksede op i en dysfunktionel familie som “uægte barn”. Der var ganske vist tre ældre halvsøskende, som tog sig af den lille dreng hjemme, men de gik undertiden også for lud og koldt vand, når deres mor var rejst væk eller skulle skrive et skuespil færdigt og ikke måtte forstyrres. Og rundt om familien i det pæne Østerbrokvarter gik snakken.

Børn vokser jo op, og i 1917 var et af børnene i denne familie netop sprunget ud som voksen. Hun hed Estrid Ott, og 


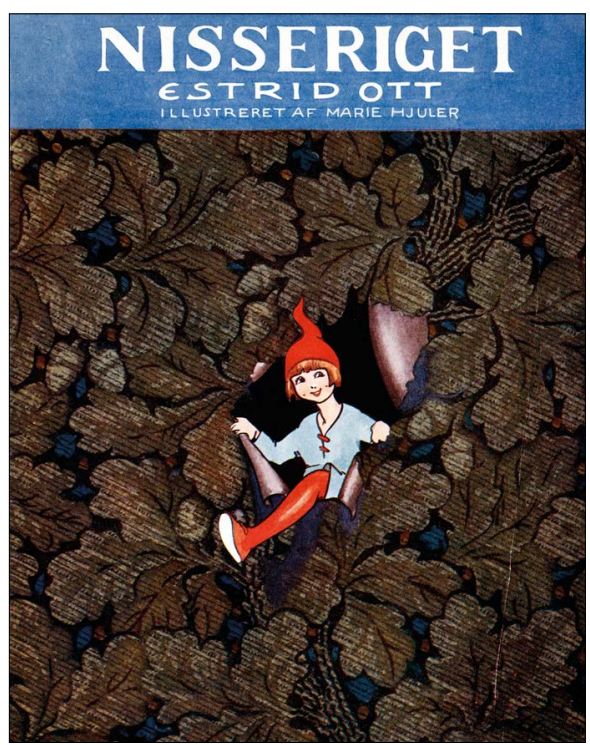

Estrid Otts debutbog Nisseriget er illustreret af Marie Hjuler (1894-1986). Det blev begyndelsen på et langt og frugtbart samarbejde om mange borneboger, og for Marie Hjulers vedkommende tillige startskuddet til en lang rakke jule- og nissemotiver, som bun blandt andet dyrkede som postkorttegner. Nisseriget fik fornylig kanon-status!

hun skulle blive en kendt forfatter, også mere kendt end sin mor, dramatikeren Olga Ott. Estrid markerede sit farvel til barndommen dét år ved at udgive sin første bog, en eventyrbog. Den kaldte hun Nisseriget. Den er stadig værd at læse.

Nisseriget handler om et fantasirige, der går i arv fra barn til barn. Der er hverken trolde eller onde stedmødre, men fantasilandet er alligevel fuldt af udfordringer - og af håb.

Bogen har en rammehistorie: En stor pige overleverer på sin 17-års fødselsdag nisseriget til sin lillebror, der er seks år og lige begyndt i skole. Han går i en traditionel skole med disciplin og skrappe voksne, og han har det ikke godt. I nisseriget, deri- mod, er hverdagen og samfundet styret og organiseret af børn; det er deres prioriteringer og deres logik, der hersker.

Drengen i bogen - han hedder Niels, ligesom Estrid Otts 11 år yngre halvbror - er blevet lagt tidligt i seng og kan ikke sove. Han opdager så en lille nisse komme ud gennem det hul i tapetet, han kradsede dagen før, hvor han ville undersøge, hvad der var bag blomstermønstret. Hans mor har straffet ham for hullet i tapetet, og slet ikke hørt på hans forklaringer - men "nu lod det til, at han alligevel havde Ret, for der var vist noget derindenfor".

Sammen med nissen forsvinder Niels ind bag tapetet og befinder sig pludselig $\mathrm{i}$ et drømmeland, hvor alle regler og (natur) love er sat ud af kraft: Man rutscher op ad regnbuer og bestemmer selv hvordan vejret skal være, og at kure på gelænderet anses for rigtigere end at bruge trappen, fordi det er sjovere.

Selvom Nisseriget er en illustreret småbørnsbog, beregnet til højtlæsning - en bog, der nok har kunnet trøste 5-7-årige, der følte sig uretfærdigt behandlet af forældre og lærere - skal man ikke kradse meget i tapetet for at opdage, at Estrid Ott også har haft en voksen-dagsorden med denne bog. Den er humanistisk-pxdagogisk; den kritiserer den pædagogik, der var den gængse i Danmark i begyndelsen af det 20. århundrede, og den peger på andre, alternative former for læring og opdragelse. Den kritiserer også voksnes opfattelse af børn, og den hylder behovet for at drømme.

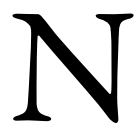
iels er en dag i ekstra dårligt humør, fordi han har meget hjemmearbejde fra skolen - han skal kunne hele Kina med floder og byer til dagen efter. Da han smutter ned i nis- 
seriget samme aften, aflægger han meget passende besøg i deres skole og oplever, hvor forandret alting kan gå til: Der er 500 børn i skolen, men kun én klasse. Børnene har ikke hjemmearbejde. De første år øver de sig kun i at læse, og de store hjælper de små - men først og fremmest leger man.

Men det bedste er alligevel den geografitime, Niels inviteres til at overvære. Det er netop Kina, der skal gennemgås, og da et stort lærred rulles ud, tror han, at der skal vises lysbilleder. Men geografitimen foregår ikke for ingenting i nisseriget, hvor man har anderledes muligheder, end i den skole Niels kender:

"Først var der nogle kinesiske Arbejdere, der gik paa Markerne og høstede Ris. 'Hvem vil være med her?' spurgte Læreren.

'Jeg! Jeg!' lød det rundt omkring.

Nisserne gik hen til Lærredet - og traadte ind i Billedet - og saa var de med.

$\mathrm{Nu}$ kom der nogle Billeder fra en kinesisk By, og da Nissefar spurgte, hvem der vilde være med, var Niels straks ivrig. Han gik hen til Lærredet, rørte med den ene Fod ved det, og pludselig befandt han sig midt i den kinesiske By.

Han oplevede de vidunderligste Ting".

Niels får - i bogens virkelighed og ved hjxlp af sin fantasi - en konkret-sanselig oplevelse af Kina. Han går i gaderne, kigger ind i de lave huse, rorer ved væggene af bambus og papir, og snakker med en jævnaldrende dreng, der ikke kan forstå, at Niels’ søster Estrid på 17 år ikke er gift endnu.

Den alternative måde at lære på giver straks resultat:

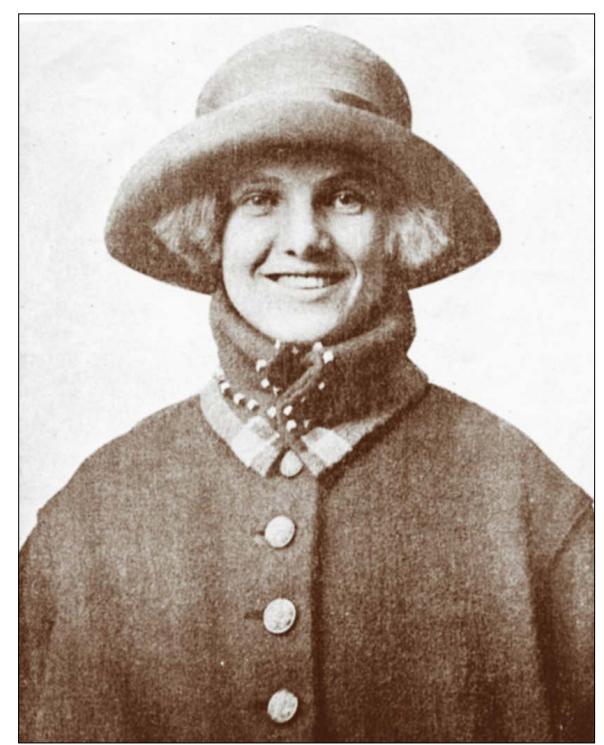

En ung Estrid Ott, fä år efter udgivelsen af Nisseriget (privatfoto).

"Da Niels den næste Dag blev hørt i 'en kinesisk By', kunde han det saa godt, at Lærerinden sagde, at man skulde tro, han havde været i Kina. Det havde han jo ogsaa". ${ }^{4}$

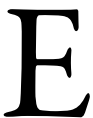
strid Ott sætter sin vision om den ideelle skole ind i en fantastisk eller eventyrlig fortælling, beregnet for mindre børn - men visionen var faktisk allerede tæt på at være realiseret. Hun havde selv stiftet bekendtskab med den i det ene, lykkelige år, hun var elev på Det danske Selskabs Skole, en privatskole på Frederiksberg, der blev drevet af en af Ott-familiens venner, filosoffen, sociologen og pædagogen C.N. Starcke (1858-1926). Starcke, der også var med ved oprettelsen af Det radikale venstre i 1905, men siden forlod partiet og stiftede Danmarks Retsforbund i 1919, var en multibegavet tænker og praktiker med 


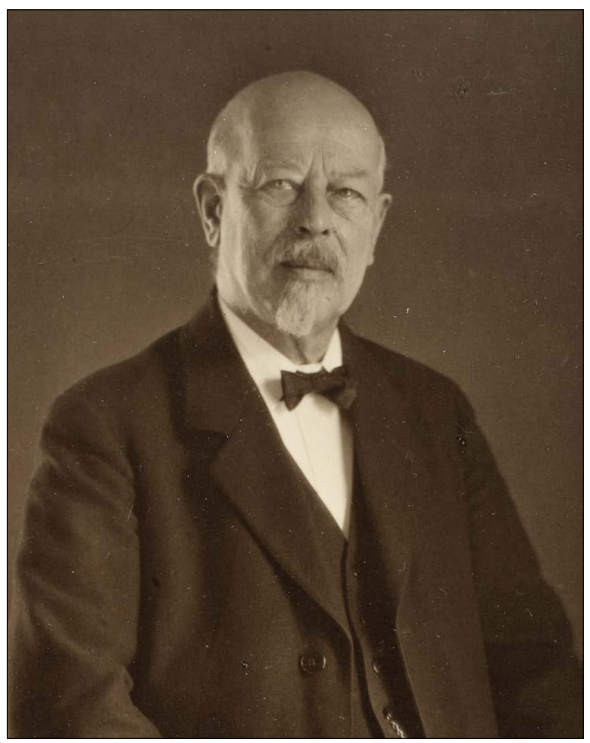

C.N. Starcke (1858-1926), var dr.phil.på en afhandling om Feuerbach, men blev iser kendt $i$ samtiden som sociolog og padagog - og som den, der grundlagde Danmarks Retsforbund i 1919. Han var far til politikeren Viggo Starcke (1895-1974). Foto: Det Kongelige Bibliotek, Kort- og Billedsamlingen.

store tanker om Danmarks fremtid, dvs. børnene. Hans skoleforsøg indledtes 1899, men skolen måtte lukke af økonomiske årsager i 1911. Forældre, også dem, der regnede sig for progressive, satte hellere deres børn i mindre eksperimenterende, men fagligt stærke skoler som Borgerdydskolen (for drenge), Ingrid Jespersens eller Nathalie Zahles skoler (for piger) - og til nød i Hanna Adlers fællesskole på Sortedam Dossering.

Starckes skole var også en skole for både piger og drenge; han kaldte den en "fri skole", og betegnelsen er ganske dækkende, for mange af hans ideer foregriber kulturradikalismens reformpædagogik, som officielt kom til Danmark i 1920erne og som med Vanløse-forsøgene
1924-28 fik navnet "den frie skole". Starcke var en flittig skribent, og hans pædagogisk-filosofiske artikler, skrevet mellem 1897 og 1910, er samlet i bogen Skoletanker fra 1927.

I Starckes skole lærte de mindste børn udelukkende ved at bruge øjne, ører og hænder, og han anvendte i vidt omfang billeder, fordi han mente det styrkede barnets fantasi, dets kognitive udvikling, og derfor også den selustendighed, der var alfa og omega for socialliberalisten C.N. Starcke. Først når barnet havde lært at læse, kom brugen af tekst, og altid kun som supplement.

Starcke beskriver, hvordan han mener (lære)bøger disciplinerer børn ved at tage deres egne billeder fra dem:

"Man lærer dem at forsømme at se med deres egne øjne (...) de lærer at mistro deres erindring. (I stedet for kun at læse om tingene) maa opgaven være at give dem tingene til undersøgelse (...) saa kan man bagefter give dem en bog $(. .$.$) som støtte$ eller opfriskningsmiddel".

$\mathrm{N}$ iels' besøg i Kina i geografitimen i nisseskolen kunne være den estrid ott'ske version af Starckes ideer om sanselig indlæring. I nisseriget læste børnene heller ikke lektier. Starcke ville have bifaldet dette, for han mente også, at de mindste børn kun skulle lave "spontant hjemmearbejde". For ham var det vigtigt ikke at overskride barnets lystgrænser; han tvivlede ikke på, at pligtfølelse kom af sig selv, hvis man gav meningsfyldt og lystfremmende (skole) arbejde.

Det danske Selskabs Skole benyttede integreret undervisning i f.eks. dansk, regning og geografi, og børnene arbejdede 


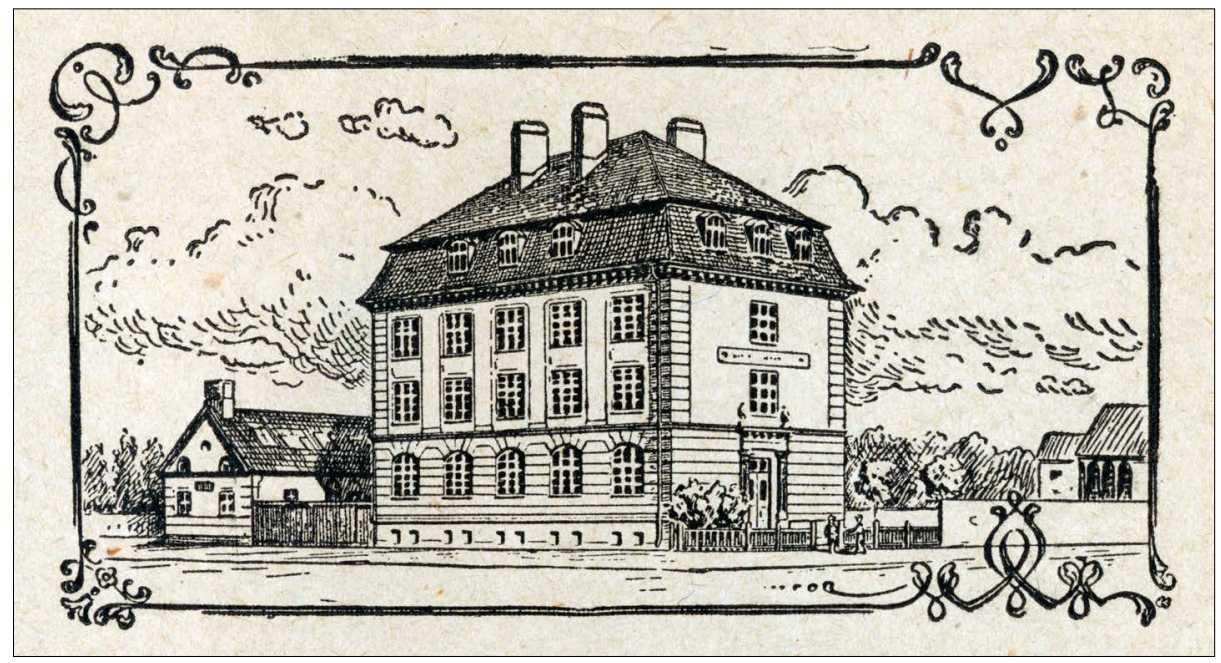

Det danske Selskabs Skole på hjørnet af Forchhammersvej og Steenstrups Allé, Frederiksberg. Bygningen rummer $i$ dag en specialinstitution. I Skoletanker. Udvalgte pædagogiske Afhandlinger fra $1927 \mathrm{og}$ i skolens ärsberetninger kan man lase om de principper han grundlagde og drev sin skole på. Starcke, der også gjorde sig tanker om sprogets brug, brugte selv en talesprogsner retskrivning, udformet af reformivrige sprogfolk. Han skrev navneord med smát, og kunne, skulle og ville uden det stumme 'd'. Han brugte også pausekomma. Tegning fra skolens årsskrift.

sammen om projekter, også på tværs af aldersgrupper. Karaktergivning og eksamen eksisterede ikke i de små klasser, og hvad disciplin angik mente Starcke, at den pædagogik, der tog udgangspunkt i barnets egne behov ville overflødiggøre ydre disciplin. Prygl var forbudt på hans skole.

Starckes skepsis overfor boglig indlæring kom også til udtryk i hans holdning til den tids formalistiske modersmålsundervisning. Børn skal ikke opøve lasefærdighed, men sprogfærdighed, mente han. Sproget er ikke en samling ord, det er et middel til at udtrykke tanker. Også her brugte han billeder, som han lod børnene undersøge, beskrive og fortælle om. "De sætninger, som barnet ved hjælp af en saadan billedanalyse selv danner, har en ganske anden værdi for det, end tilsvarende sætninger som det finder i en bog”. 6 Billedanalysen vænner barnet til at skærpe iagttagelsesevnen ved at se nøjagtigt, bevidst og metodisk, samtidig med at den vænner det til kun at bruge ord, som det forbinder en mening med.

Starcke ville fremelske og støtte selvstændighed hos børnene; det udtrykkes ved antologien Skoletankers motto: "Lær barnet at leve selv".

Selvstændighed er alt. Men Starckes motiv til at udvikle og uddanne selvstændige, modige, viljestærke, handlekraftige og fantasifulde mennesker har - også - et politisk-ideologisk sigte.

I artiklerne samlet i Skoletanker gøres der nøjere rede for de holdninger, der ligger bag Starckes pædagogiske visioner. Det er ikke den individuelle lykke, der er målet; dyrkes den, ville vi ende i anarki, mener han, og det er her han tydeligst adskiller sig fra den kulturradikale 
udgave af reformpædagogikken. "Maalet maa være at skaffe plads for individets rigeste og friest mulige udvikling af den samfundsnyttige natur, og at hæmme alt det, som kunne vise i en anden retning"?

"Samfundsnytte" skabes ifølge Starcke af individer, der arbejder til deres evners grænse for en fortsat vækst af de fælles ideer. Det mål kan kun nås ved at begrænse den enkeltes (økonomiske) initiativ mindst muligt. Som eneste restriktion foreslås indført en beskatning af de oprindelige værdier (jordrente), da ejendomsforholdene er grundlæggende uretfærdige.

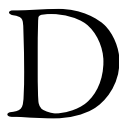
et er i kortform Starckes - og hans inspirator, den amerikanske filosof og $ø$ konom Henry George's - ideer. Den klippefaste tro på at fortsat vækst vil være til gavn for alle, at samfundet ikke vil ændre sig med den påbudte, fortsatte vækst, og at statens rolle som administrator også kan fastlægges én gang for alle, kunne være en del af forklaringen på at georgismen aldrig fik nogen markant parlamentarisk position

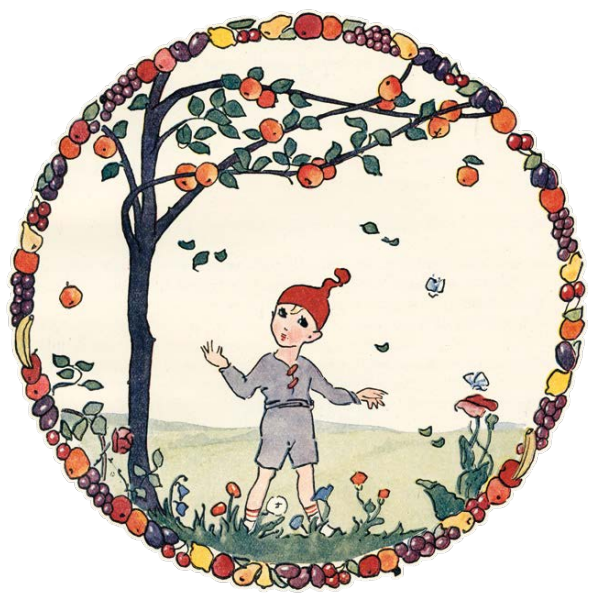

(i Danmark i skikkelse af Retsforbundet). Starckes pædagogiske teorier og praktikker var til gengæld livskraftige og langt forud for deres tid.

$\mathrm{L}$ ille Niels Ott kom ikke i Starckes skole, for den var lukket i 1917. Til gengæld fik han et nisserige, som han bar med sig i forskellige former i sit tumultariske liv. Og giveren, hans halvsøster Estrid, blev journalist og forfatter og rejste allerede som purung verden rundt og holdt foredrag om pædagogik, spejderbevægelse og børns vilkår, og derefter vendte hun hjem med planer om at udgive en daglig avis, der skulle være skrevet til og af børn - for, som hun siger i et interview i 1920:

"Børn er blevet pålagt tavshed alt for længe! Børn har længsler og hemmeligheder, som de - selvom de fik lov - ikke kan dele med deres forældre. Men de kan dele dem med mig. Og med hinanden".

Avisen blev ikke til noget. Til gengæld skrev Estrid Ott mere end 80 bøger, hvor små og større børn får stemme.

\section{Noter}

1 Bruno Bettelheim: The Uses of Enchantment. The Meaning and Importance of Fairy Tales (1975, da. forkortet udg. Eventyrets fortryllelse, 1991).

2 Nisseriget, s. 4.

3 Nisseriget, s. 22-23.

4 Nisseriget, s. 25.

5 Skoletanker, s. 78.

6 Skoletanker, s. 118.

7 Skoletanker, s. 11.

8 New York Times, 31.10 .1920 (oversat af forf.)

Fra Nisseriget. 